\title{
THEORETICAL REVIEW ON INDONESIAN ACADEMIC LEGAL EDUCATION IN CONJUNCTION WITH ASEAN ECONOMIC COMMUNITY ERA
}

\author{
Ariawan Gunadi * \\ * Lecturer of International Business Law, Faculty of Law University of Tarumanagara

\section{Article Info} \\ Received : 3 November 2014 | Received in revised form : 11 December 2014 | Accepted :29 December 2014 \\ Corresponding author's e-mail : ariawangun@gmail.com
}

\begin{abstract}
Indonesia will be welcoming the ASEAN Economic Community in 2015 as a multilateral agreement to create integrated regions such as: (a) a single market and production base, (b) a highly competitive economic region, (c) a region of equitable economic development, and (d) a region fully integrated into the global economy. These characteristics are interrelated and mutually reinforcing in a sense that overall development would not be complete without total completion of the previous sector. This article discusses the participation of Indonesia as part of ASEAN as a single market and production base, through free flow of services which targets higher education in law. The author researched that Indonesian higher education system still faces issues, especially in legal education. As a result, the quality of Indonesian law graduate still varies. Indonesian legal education is special in nature since it is considered profession and regulated by code of ethic. According to the author, legal education should be integrated with profession organization so that upon graduation, law graduates can directly conduct internship according to their desired profession and compete against ASEAN law graduates.
\end{abstract}

Keywords: Indonesia, AEC, international trade, higher education sector, legal education,

\begin{abstract}
Abstrak
Indonesia akan menghadapi ASEAN Economic Commmunity pada tahun 2015 sebagai realisasi perjanjian multilateral untuk menciptakan wilayah terintegrasi seperti: (a) pusat produksi dan pasar tunggal, (b) wilayah ekonomi yang kompetitif, (c) wilayah yang memiliki perkembangan ekonomi yang memadai, dan (d) wilayah yang terintegrasi dengan ekonomi global. Karakteristik ini saling berhubungan dan mendukung dalam arti semua perkembangan ini tidak akan lengkap tanpa terpenuhinya semua persyaratan tersebut. Artikel ini membahas partisipasi Indonesia sebagai anggota ASEAN mengenai potensi pendidikan tinggi dalam bidang hukum sebagai sektor jasa. Akibatnya kualitas lulusan hukum di Indonesia masih beraneka ragam secara nasional. Pendidikan hukum itu sifatnya khusus karena berupa profesi dan diatur oleh kode etik. Menurut hemat penulis, seharusnya pendidikan hukum terintegrasi dengan lembaga profesi, sehingga lulusan sarjana hukum sudah memiliki sertifikasi untuk langsung magang menurut profesinya masing-masing dan bersaing dengan lulusan hukum dari ASEAN.
\end{abstract}

Kata kunci: Indonesia, AEC, perdagangan internasional, pendidikan hukum

\section{Introduction}

Association of South East Asian Nations (ASEAN) has finally agreed to form a multilateral agreement in face of global trend of free trade. Termed as ASEAN Economic Community, it principally enshrines the term "free flow of services"

${ }^{1}$ Asean Secretariat, 'ASEAN Economic Community Blueprint' (Jakarta: January 2008) <http:// www.asean.org/ archive/5187-10.pdf> accessed 30 November 2014 
this meant that the AEC will be responsible to form the Coordinating Committee on Services. Specifically, Ministerial bodies shall be in charge when relating to sensitive sectors as financial services and air transport.

From an international law aspect, ASEAN 2020 has established a precursor to a peaceful and stable region ${ }^{2}$ with the requirement that sovereign government should manage the exercise of power in legal terms to their subject through a just Rule of law and independent legal system ${ }^{3}$. As a comparison, the International Court of Justice will only exercise its jurisdiction when state member requests for a binding decision. But in such case, ASEAN lacks a supra national authority to enforce the decisions made by states. It is why though the regulation of ASEAN is universal, state members will only face moral and financial risks, but no legal binding risks. Categorization of legal as a service sector raises an interesting question in AEC since professions are commandeered by person and regulation by government or professional institution. In that sense

Aside from the subject, the liberalized service comprises of prioritized service sectors and other service sectors. Prioritized sectors include air transport, e-ASEAN, healthcare and tourism, while other sectors shall be regulated accordingly. The interesting thing is that legal services sector has yet to be regulated in a clear manner. Considering the multiple jurisdiction among states, surely there are problems concerning contract or legal enforcement of decisions that affects multinational business environment. Grant stated his opinion about the ASEAN legal system as the following:

"Doing business in the Association of Southeast Asian Nations (ASEAN) is gradually getting easier thanks to the elimination of tariff barriers, expansion of supply chains and gradual harmonisation of customs procedures.

Yet one of the big "soft" barriers to greater ASEAN integration, and one which makes life hard for multinationals and ambitious local companies alike, are the differing jurisdictions across the 10-member bloc....Singapore and Malaysia's legal systems are based on English common law, while Indonesia's is rooted in the Dutch framework left by its former Dutch colonial rulers. Thailand was never colonised, but its legal system is a hybrid of French, German and English common law. Vietnam, a former French colony, is an incoherent mix of old Soviet law, common law, European civil law and Asian influences."

He then cited that major companies such as Lafarge, Holcim would have to understand the various laws in each region while similarly pharmaceutical companies in Singapore that wishes to expand elsewhere such as Thailand, Malaysia or Indonesia will have to appoint their respective lawyers. While for major companies, this may not

${ }^{2}$ ASEAN Secretary-General Le Luong Mingh reported in "ASEAN region on track for 2015 integration" (7 July 2013) Inquirer Business (available online:http://business.inquirer.net/130941/asean-regionon-track-for-2015-Integration (last accessed 9 July 2013))

${ }^{3}$ Sundaresh Menon, 'ASEAN Integration Through Law'< http://app.supremecourt.gov.sg/data/ doc/ ManagePage/4943/ASEAN\%20Integration\%20Through\%20Law\%20Project\%20Keynote.pdf> accessed on 2 December 2014; A V Dicey, Introduction to the Study of the Law of Constitution, 3rd Ed (London: Macmillan, 1889) at 175,181-183.

${ }^{4}$ Jeremy Grant, "Legal hodge-podge frustrates Asean harmonization" (21 August 2014) < http:// blogs.ft.com/ beyond-brics/2014/08/21/legal-hodge-podge-frustrates-asean-harmonisation/> accessed 28 November 2014 
be an issue, but local businesses may be discouraged from venturing even further in ASEAN scope due to high legal cost such as contract drafting, trademark registration, permit management etc.

The remainder of this paper is organized as follows. The next section of this paper provides the legal framework of the Indonesian legal education services and its compatibility with AEC. Section III explains the role of the government supervisory agency in national legal education. Section IV presents argument for a sustainable legal education and training for law graduates to become lawyer and consultants. The last section of this paper provides readers with recommendations and conclusion.

\section{Framework of Indonesian Higher Education in Law and Its Compatibility with AEC Towards Advocates and Legal Consultants as Legal Graduates}

From a contemporary perspective, Indonesian regulation on higher education was previously laid out by Law No 20 Year 2003 concerning National Education System which compiled higher education as a part of formal education. The government considered higher education as a part of structured and tiered educational path a university consists of several faculties conducting academic and/or professional education in several disciplines. ${ }^{5}$ And in the development, higher education met great demands from the society due to increasing number of young generations.

And so the Law was revised into Law No 9 Year 2009 concerning Educational Legal Institution (Law No. 9 Year 2009 / BHP Law). The new law acts as a screen that the government should not limit itself with regard to national issues but also to sensitive special issues such as economy, ownership and education. ${ }^{6}$ Ensuing debates concerning higher education institution continues with the dispute that it no longer preserves the essence of education itself. ${ }^{7}$ Purbayanto argues 3 points to the flaw such as: (1) lack of accommodation to the poor; (2) vague notion of government responsibility in educational activity; and (3) misconception of articles in the law.

The first point was evident since Law No 9 Year 2009 failed to secure larger parts for underprivileged to obtain higher education, but instead regulates issues on privatization whether explicitly (such as article 43 paragraph 1 regarding business entity and article 57 regarding bankruptcy) or implicitly (article 38 paragraph 1 regarding accrued benefits) On the other hand, the government also set out a low quota of $20 \%$ for underprivileged students without clear guidance on the mechanism, affordability or channels to apply for such opportunity. ${ }^{8}$ As result, prior to the enactment of BHP Law, universities have raised the fees for favourite subjects above market Price under the guise of numerous mechanisms such as independent exam.

Government responsibility remains low despite the mandatory education state budget of 20\% from the total state budget (Anggaran Pendapatan Belanja Negara Negara/APBN). Law No. 9 Year 2009 became an opportunities for state university

${ }^{5}$ Article 1 par. 11 of Law No. 20 Year 2003 concerning National Education System

${ }^{6}$ Siswoyo, Dwi, dkk. 2007. Ilmu Pendidikan. Yogyakarta: UNY Press.; Anonyumous, Dasar Hukum Pendidikan di Indonesia. http://englishclass-b.blogspot.com/2013/12/dasar-hukum-pendidikan-di-indonesia.html

${ }^{7}$ Darmaningtyas et al. Tirani Kapital Dalam Pendidikan : Menolak UU BHP (Badan Hukum Pendidikan). Jakarta: Damar Press, 2009, p. 145.

${ }^{8}$ Ari Purbayanto, Menyingkapi Pro dan Kontra UU BHP, http://sa.ipb.ac.id/index.php/sorotanutama/16-menyikapi-pro-dan-kontra-undang-undang-bhp.html, diakses tanggal 5 Desember 2014 
to cover the "losses" due to "sacrificing" available seats by commercializing the remaining seats. Article 41 paragraph 6 and 9 of Law No. 9 Year 2009 stated that half of the operational cost is covered by government and the public. The reduced responsibility of government in financing state university also impacted the tuition cost in favourite state university. Law No. 9 Year 2009 also opens the opportunity for foreign party to participate into Indonesia's higher education sector, which threatens national integrity. The effort to liberalize education has gone a long way since Indonesia ratified the free agreement treaty sponsored by WTO in 1994. Such agreement stated that service sectors including higher education is included in the reach of global market and exists as tradeable service commodity.

The last issue is concerning the mis-coordination of articles in Law No. 9 Year 2009 that reflects poor patching effort, designed only to fulfil target and undermine quality. Dr. Arya Hadi Darmawan stated such chaos as the inconsistency of logic between articles. ${ }^{9}$ For example article 4 of Law No 9 Year 2009 stated that legal educational institution as a non profit organization while article 57 and 58 stated that such institution may propose insolvency. On the other hand, article 4 of Law No. 9 Year 2009 mentioned profits (Sisa Hasil Usaha/SHU) versus Article 38 paragraph 1 and 3 concerning excess of activity (Sisa Hasil Kegiatan). Having stirred the notion between private gain and public benefit, Law No. 9 Year 2009 repeatedly faced law suits in the Constitutional Court from dissatisfied parties ${ }^{10}$ and finally was repealed. ${ }^{11}$

To this extent, legalists believe that lecturers should have certain guides and references in carrying out education activities and avoid subversion. Not only that, as individuals, they should also be managed into a structured organization to: a) align national interest through education; b) to create assurance in terms of lecturer ranking system; c) to create a centralized data basis for qualified lecturers; and d) conduct continuous assessment towards the lecturer and students itself.

In the development Higher Education Institute (HEIs) consists of faculties conducting academic and/or professional education in disciplines that align with a set profession. In comparison, a college conducts academic and professional education in one particular discipline. Meanwhile, an academy and a polytechnic are vocational HEIs that provide professional skills and diploma degrees.

Based on their status, the HEIs in Indonesia can be divided into two groups: the public HEIs and the private HEIs. The public HEIs are under the jurisdiction of the state treasury law, education system law and civil servant law and are treated as part of the ministry. Private HEIs are regulated under the Foundation and Education System Law, and are considered the business arm of the foundation. Brodjonegoro argues that, under these regulations, the HEIs have no independent means of carrying out their mission as a moral force and they become less accountable and less innovative.

There is also a difference in the admissions processes. The admission process in public HEIs is done through the national examination for higher education (Seleksi Penerimaan Mahasiswa Baru). As seats in public HEIs are limited, a prospective applicant will have to compete nationally for a specific field. Usually the applicant submits for acceptance to two to three prospective programs. This system ensures

\footnotetext{
${ }^{9}$ Ibid.

10 Anonymous (7 February 2009) Mendiknas: Silahkan Gugat UU BHP< http://nasional.kompas. com/read/2009/02/07/15021516/mendiknas .silakan.gugat.uu.bhp>, accessed 6 December 2014

${ }^{11}$ Lucia Ratih Kusumadewi and Antonius Cahyadi, The Crisis of Public Universities in Indonesia (29 June 2013) <http://www.isa-sociology.org/universities-in-crisis/?p=1010> , accessed 6 December 2014
} 
that only those with the highest scores are admitted. Admission into private HEIs is considered to be less competitive. As several private HEIs have a very good reputation, admission to these institutions is, however, as competitive as it is for public HEIs.

Indonesian legal education is conducted by law schools (under university management) under the direction of Directorate General of Higher Education of Republic of Indonesia. While law school was originally established to meet demands for legal employees in district court ${ }^{12}$, further development allowed opening of other branches of professions such as advocates, notary and legal academicians. State universities such as the University of Indonesia, Gadjah Mada University and University of Padjajaran were among the first to sprung up and followed after by private universities such as Tarumanagara University and Padjajaran University to cater increasing public demands. ${ }^{13}$

Reksodiputro pointed out that behind all of these developments, Indonesian law schools face some issues both for law school. ${ }^{14}$ The first problem would be the faculty development. Law schools have yet to update their library and law professors have certain reluctance to do research in foreign or international materials. Both infrastructure and personnel deficiencies have caused law graduates to be unprepared when working in law firm or business companies. ${ }^{15}$

The second problem is curriculum development, which includes active teaching in small classroom settings within depth case analysis. This means that some ingraining changes in the methodology of teaching should be encouraged as opposed to the theoretical pedagogy learning. Mochtar Kusumaatmadja proposed the training of 'professional' education aspect ${ }^{16}$ as the following:

(a) legal skills training); and

(b) establishment of Work Unit under the auspice of Law Laboratory to prepare "case materials" for litigation and non litigation training.

It should be noted however, that in the past the task to find solutions to the problems and to do the necessary reform in legal education will be the responsibility of the deans and further comparative studies with overseas law faculties to obtain better knowledge of international development in law.

\section{Role of Government Supervisory Agency in National Legal Education}

\section{A. Insight of BAN-PT as regulator}

Higher education is of great importance to the future on Indonesians, which is also accommodated within article 31 of 1945 Constitution that every citizen is entitled for

12 Anonymous, 'Info Lengkap Fakultas Hukum', <http://old.ui.ac.id/id/academic/page/fh> accessed on 12 December 2014

${ }_{13}$ Anonymous, 'Preparing An Entrepreneurial Generation That Will Become Future Leaders' < http://www.taruma nagara.ac.id/read-isi_berita-eng-468.html> accessed 8 December 2014

14 Marjono Reksodiputro,' Challenges to Legal Education in Indonesia'. <http://www.aseanlawassociation.org /docs/w3_indo.pdf> accessed on 12 December 2014

15 Anonymous, 'Mimpi Sarjana Hukum Menjadi Pengacara' < http://www.hukumonline.com/ berita/baca/hol8367/mimpi-sarjana-hukum-jadi-pengacara>, accessed on 12 December 2014

${ }^{16}$ Marjono Reksodiputro, Perkembangan Kurikulum Pendidikan Hukum (Beberapa Catatan Memperingati Satu Abad Pendidikan Hukum di Indonesia), <http://www.amicorumdjokosoetono.com/index. php/artikel-karangan-lepas-alumni/44-perkembangan-kurikulum-pendidikan-hukum-beberapa-catatanmemperingati-satu-abad-pendidikan-hukum-di-indonesia> accessed on 12 December 2014. 
national education. And therefore the government established National Accreditation Board for Higher Education (BAN-PT) in 1994 as the sole accreditation board (in this case by the Ministry of National Education). BAN-PT is a non-structural institution under the Ministry of National Education, which has the function of the quality assessment of higher education, including State Universities, Service, Religious, and Private. ${ }^{17}$

The Ministerial Decree of Ministry of Education and Culture No.0326/U/1994 orders the National Accreditation Board for Higher Education (BAN-PT) to develop and implement accreditation system for HE programs. ${ }^{18}$

After the National Education Act No. 20/2003 and the Directorate General Directive of Higher Education Long Term Strategy 2003 - 2010, and then the Government Regulation for the National Standards for Education No. 19/2005, a new Ministerial Decree provided a new mandate for Accreditation Board for Higher Education (BAN-PT) to improve and implement the accreditation system for HE programs and maintain the accreditation system for HE institution.

BAN-PT's experience in dealing with accreditation process faced great obstacles due to the huge number of higher education institutions existing nationally with some geographical constraints. The process has been mired by limited assessors within a limited time between 4 or 5 consecutive batches every year. Therefore, about $2 \%$ to $3 \%$ of the accreditation processes would normally require further scrutiny and re-evaluation because of inappropriate placement of assessors and unsatisfactory performed assessors. ${ }^{19}$

This challenge has been ongoing for the last five years after the number of accreditation applicants getting bigger and bigger due to government imposition toward quality. Many universities even established peer group organizations to help develop internal assessor candidates, recruitment, programs grouping, etc.

The other difficulties are related with the limited amount of the government supporting fund and the administration procedure in fund delivery for assessor deployment. Prof. Dr. Sutjipto, Chair of Assessor Team for BAN-PT even stated that only earlier applicants who have submitted accreditation forms and their documents will be entitled to assessment process. ${ }^{20}$

There are also positive sides of the BAN-PT progress. The government and society recognition of HE program accreditation result issued by BAN-PT is continuously increasing.

The level of accreditation result profile is considered as one of the requirements for an education institution to open new programs. The accreditation level is also used as one of the requirements in some private companies in their recruitment program for new workers.

Recently the accreditation trend has been implemented by engineers. Moreover,

${ }^{17}$ Anonymous, 'BAN Accreditation of the Ministry of National Education of Republic of Indonesia', <http://feb.ugm.ac.id/en/accreditation/ban-pt-accreditation.html>, accessed on 4 December 2014.

18 Ana Suhaenah, Adam Pamudji Rahardjo, BAN-PT, the National Accreditation Board for Higher Education with One Decade Experience in Indonesia. < http://siteresources.worldbank.org/EDUCATION/ Resources/indonesia ban-pt.pdf> accessed 7 December 2014.

19 Anonymous. 2011'Kajian Analisis Sistem Akreditasi Program Studi dalam Rangka Reformasi Birokrasi Internal'< http://luk.staff.ugm.ac.id/atur/rbi/AkreditasiProdi.pdf> accessed on 3 December 2014.

${ }^{20}$ Anonymous (9 November 2013) 'Dana Terbatas, Belum Semua PT Terakreditasi'< http://www. pikiran-rakyat.com/node/257882> accessed 6 December 2014. 
the recognition also comes from the Asia Pacific Economic Cooperation Association, Engineering Commission. This institution has accepted that graduates from the accredited programs with A or Part of B level may apply for APEC Engineer Certification. $^{21}$

The challenging experiences faced by BAN-PT comprises of:

1. The huge amount of programs and HEI

BAN-PT currently organizes 4 to 5 consecutive batches each year and typical assessment will require two month of process and report to BAN-PT. For every accreditation batch there are 400 accreditation applicant programs and 200 assessors available. Usually, three day desk evaluation process is facilitated by the secretariat in a big conference room. Assessors will then conduct a three day site visit for each program. It is expected that new assessors should be and its quality increased to speed up the recruitment process.

2. Prolonged preparation for Accreditation for Higher Education Institutions

For years, the HE Institution accreditation has been disseminated to the HE society in parallel with Government Directives on National Education Standard. For starters, this has motivated some HE institutions to establish and implement internal QA system. However, results would undoubtedly require more time.

3. Setting up and managing an independent accreditation institutions

Meeting and dissemination programs with some professional and educational associations on professions such as doctor and engineering have been carried out in the last two years. Coordinating several associations in same or similar fields may prove to be a problem because of different background, vision and mission of the associations. This situation shows that the government will have to maintain a key role of QA system manager for HE in Indonesia.

\section{B. AEC regulation on higher education as service sector:}

AEC has considered trade services as part of trade facilitation to reduce transaction costs in ASEAN with 2 purposes: i) for person; ii) for capital owners. As stated in AEC Blueprint ${ }^{22}$ Article 21 of section A2 concerning free flow of services:

"20. Free flow of trade in services is one of the important elements in realising ASEAN Economic Community, where there will be substantially no restriction to ASEAN services suppliers in providing services and in establishing companies across national borders within the region, subject to domestic regulations. Liberalisation of services has been carried out through rounds of negotiation mainly under the Coordinating Committee on Services. Negotiation of some specific services sectors such as financial services and air transport are carried out by their respective Ministerial bodies. In liberalising services, there should be no back-loading of commitments, and preagreed flexibility shall be accorded to all ASEAN Member Countries.

21. In facilitating the free flow of services by 2015, ASEAN is also working towards recognition of professional qualifications with a view to facilitate their movement within the region.

${ }^{21}$ The Institution of Engineers Singapore (25 February 2013) , 'Asia Pacific Economic Cooperation Engineers Register' < http://www.ies.org.sg/pageview.php?page id=346>. accessed 6 December 2014.

${ }^{22}$ See note 2. p. 12. 
Actions:

i. Remove substantially all restrictions on trade in services for 4 priority services sectors, air transport, e-ASEAN, healthcare and tourism, by 2010 and the fifth priority services sector, logistics services, by 2013;

ii. Remove substantially all restrictions on trade in services for all other services sectors by 2015 ;

iii. Undertake liberalisation through consecutive rounds of every two years until 2015, i.e.2008, 2010, 2012, 2014 and 2015;

iv. Target to schedule minimum numbers of new sub-sectors for each round: 10 sub-sectors in 2008, 15 in 2010, 20 in 2012, 20 in 2014 and 7 in 2015, based on GATS W/120 universe of classification;

v. Schedule packages of commitments for every round according to the following parameters:

- $\quad$ No restrictions for Modes 1 and 2, with exceptions due to bona fide regulatory reasons

- 11 (such as public safety) which are subject to agreement by all Member Countries on acase-by-case basis;

- $\quad$ Allow for foreign (ASEAN) equity participation of not less than 51\% by 2008, and $70 \%$ by 2010 for the 4 priority services sectors; not less than 49\% by 2008, $51 \%$ by 2010 , and $70 \%$ by 2013 for logistics services; and not less than $49 \%$ by $2008,51 \%$ by 2010 , and $70 \%$ by 2015 for other services sectors; and

- $\quad$ Progressively remove other Mode 3 market access limitations by 2015;

vi. Set the parameters of liberalisation for national treatment limitations, Mode 4 and limitations in the horizontal commitments for each round by 2009;

vii. Schedule commitments according to agreed parameters for national treatment limitations, Mode 4 and limitations in the horizontal commitments set in 2009;

viii. Complete the compilation of an inventory of barriers to services by August 2008;

ix. Allow for overall flexibilities, which cover the sub-sectors totally excluded from liberalisation and the sub-sectors in which not all the agreed parameters of liberalisation of the modes of supply are met, in scheduling liberalisation commitments. The scheduling of liberalisation commitments in each round shall be accorded with the following flexibilities:

- $\quad$ Possibility of catching up in the next round if a Member Country is not able to meet the parameters of commitments set for the previous round;

- $\quad$ Allowing for substituting sub-sectors that have been agreed to be liberalised in a round but for which a Member Country is not able to make commitments with subsectors outside the agreed sub-sectors; and

- $\quad$ Liberalisation through the ASEAN Minus X formula.

$\mathrm{x}$. Complete mutual recognition arrangements (MRAs) currently under negotiation, i.e. architectural services, accountancy services, surveying qualifications, medical practitioners by 2008 , and dental practitioners by 2009 ;

xi. Implement the MRAs expeditiously according to the provisions of each respective MRA;

xii. Identify and develop MRAs for other professional services by 2012, to be completed by 2015; and 
xiii. Strengthen human resource development and capacity building in the area of services."

AEC aims to make higher education available for its citizens by allowing the enhancement of educational quality from qualified personnel's or to invite investors into building educational facilities at developing ASEAN state members.

The pathway would be through Mutual Recognition Arrangements between states and for the time being, the agreement has been specifically aiming at profession instead of higher education regulation. As result, AEC regulations on higher education service have only affect the ownership allocation for investors or qualification for experts.

Naim Yaakub mentioned the impact of AEC towards higher education comparing to ASEAN state members as the following ${ }^{23}$ :

\section{A. Brunei Darussalam}

Brunei has three Higher Education Institutions (HEI) offering certificate, diploma and degrees. One of the innovations in HE is to introducte of "Disco very Year" wherein students move out of the classroom for a semester or an academic year to gain community. Universiti Brunei Darussalam students, for example, may opt to enroll in a Study Abroad Programme, undergo an internship with appropriate companies or agencies, plan and implement community outreach programmes, or create a start up and innovation enterprises.

Brunei is currently striving to achieve Vision 2035: "To build a first class education system that provides opportunities for every citizen and residence". All of which is for HEI to prepare students who will meet the human resource needs of the country, Brunei aims for $40 \%$ participation rate in higher education

\section{B. Cambodia}

Cambodian HEI has existed for only 30 years old due to past upheaval. Institutions of Higher Education in Cambodia offers various types and titles of degrees and diplomas including Master's degrees, Bachelor's degrees, professional diplomas, postgraduate diplomas and diplomas. Recently, higher education institutions in the region have also lent their influence to the system aside from French, Soviet and Vietnamese influences. The current HEI in Cambodia are supervised by 12 different ministries/government institutions

\section{Lao PDR}

Lao HEI has atotal of 160 Colleges and 5 Universities are offering Higher Diploma Program, Bachelor's degree, Master's Degree and Ph.D., 77 of which are private. Private post-secondary education institutions may award Bachelor's Degrees by ontaining prior approval from the Ministry of Education. Laos HEI currently suffers from lack of clear vision, appropriate policy and strategy, and master plan used for higher

${ }^{23}$ Dr. Mohammad Naim Yaakub, Challenges in Education Towards The Realization of ASEAN Community 2015, <http://www.site.rmutt.ac.th/cpscworkshop/materials/sp.pdf>, accessed at 12 December 2014 
education development as to meet that of regional and international higher education in terms of quality, relevance and capacity in attractiveness and competitiveness.

The major challenges faced in higher education in Lao are to produce and provide qualified human resources in align with international standard in support to graduate from the least developed country status by 2020.

\section{Malaysia}

Malaysian HEIs can be classified into two - public and private HEIs. Public universities, polytechnics, community colleges and public colleges are examples of Public HEIs. Meanwhile, private universities, private colleges and foreign university branch campuses are examples for private entities. Malaysia promotes the 'levelingup' approach to benefit the socio-economically disadvantaged group while at the same time achieving excellence in human capital development. Under the National Higher Education Strategic Plan (NHESP), Malaysian higher education attempts to provide a solid foundation for the future by adopting seven strategic thrusts to focus on improving and empowerment of HE which are: generating public access and increasing equity, improving the quality of teaching and learning, enhancing research and innovation, strengthening of higher education institutions, intensifying internationalization, enculturation of lifelong learning, and reinforcing delivery systems of the Ministry.

\section{E. Myanmar}

The mission of HE in Myanmar is "to create an education system that can generate a learning society capable of facing the challenges of the knowledge age". The highlight in its $\mathrm{HE}$ is relatively new by introducing new assessment techniques to test the depth and breadth of knowledge, creativity, and analytical thinking of students. One of the key challenges in Myanmar HE is to create a university environment with strong research activities by expanding activities of research centers extending to international collaborations.

\section{F. Philippines}

Its higher education is notable by significant number of HEIs and large College population, with diverse program offerings. Currently its priorities lie on the efficient use of resources through the collaboration of local, regional and international stakeholders. The Phillipines Commission on Higher Education regulates and facilitates by in taking its role, responsibilities and duties in facilitating the requirements and necessary steps in improving the country's higher education sector, specifically, implementation of reforms that enable acquisition of knowledge, development of skills, values and attitudes, which will enhance productivity, globalization and competitiveness of graduates.

\section{G. Singapore}

The government of Singapore relies on HEI as their main source of income, actively recruited prestigious foreign universities to establish local campuses, with the goal of expanding access for the local student and becoming a 'hub' for the region. Singaporean 
public and private Higher Education Institutions offer degree programmes, diploma courses, certificate courses, and other post secondary qualifications across a wide range of disciplines. Singaporean HEI has developed several higher education programme as the following: Increasing Cohort Participation Rates through increased spending, Enhancing Continuing Education and Training Landscape, Maintaining Affordability of Higher Education, Cross-Border Higher Education, ASEAN Credit Transfer System, Student Exchanges, Building up SEAMEO Research Clusters in the areas of Urban, Environment and Sustainability Issues, Health and Medical Issues, and Social Sciences.

\section{Thailand}

The key trends in HE in the Kingdom of Thailand is designed to ensure that they will stay competitive in the international market place. Some of the examples are Cooperative Education and Work Integrated Learning for New Generation Workforce which foster links between higher education and the world of work. Regional Research Leaders was also established which aims to accelerate the development of university research activities nationwide to enhance national competitiveness. Regional Hub in Higher Education Provision is the latest development in Thai higher education which is currently undergoing the second decade of the national education reform with the goal to aspire toward good education quality.

In general Thailand aims to become the regional education hub in South-East Asia with the aim of increasing foreign students in Thailand up to 100,000 from the current figure of 20,000 students. The Royal Thai Government has instructed Thai universities to achieve international standards of excellence while upholding their academic freedom and social responsibility. Strength of ICT infrastructure for improving quality of higher education is also a priority including the use of the InterUniversity Network, Thailand Cyber University, the e-library ThaiLIS and the National Education Network (Ned-Net).

\section{J. Vietnam}

Vietnam underwent structure adjustments in the univ ersities to improve the quality of higher education. Some of these adjustments include improvement of higher education programs and teaching and learning methods, development of lecturing staff and higher education managers, increase in research and implementation activities in order to improve training quality, reforms in financial mechanism in order to diversify resources and improve investment efficiency, improvement of higher education management to increase autonomy, social accountability and competitiveness, and improvement in competitiveness of higher education system in international integration process.

Overall, higher education is the key to economic development as it plays significant and important roles in turning the country into industrialization and modernization.

Seeing this importance, higher educational institutions, in the future, are to be strengthened and improved in the following areas: (1) provision of fair equitable access to higher education, (2) relevance, quality and efficiency, (3) governance, financing and service

It would be best if national HEI owners also expressed the intention of enhancing the student's knowledge through an elective certificate study course providing 
knowledge on ASEAN and its impact on business, technology, and innovation. As an imperative, educational institutions should prioritize their future developments by setting up courses that can keep up with the changing business needs as well as conducting university research with partners in the industry in order to foster commercial applications. ${ }^{24}$

\section{Sustainable Path for Legal Higher Education in ASEAN}

So what is the ideal structure for higher education in ASEAN? Based on the author's experience, legal education is tightly knitted with higher education sector development, especially on training for lawyers and legal consultants.The legal profession as a service should not be considered negatively especially by the local practitioners. Taib cited the potential disadvantages ${ }^{25}$ to the legal professions are:

i. Overcoming differences: it is difficult for ASEAN countries to interconnect regional legal qualifications given such differences. However, it is worth to note that the European Union, have been able to set up the Council of Bars and Law Societies of Europe, and issued initiatives for free flow of workers in the region.

ii. Need to establish a stronger and effective regulatory regime: A national Law Society would find it hard to regulate the conduct of its lawyers who are practicing in other member countries. Therefore it would be best if states could agree to a united bar standard for Intra-ASEAN level. Such an example maybe seen in Indonesian bar organization (PERADI) which provide assimilation training and exam for 58 foreign lawyers, and graduated 17 people in August 2014. ${ }^{26}$ The main purpose of the training would be to focus on the code of ethics, registration and a considerable sum of registration fees to ensure that foreign lawyers can meet up to the national demand and international standard instead for conducting predatory practice to national market.

iii. Fear from local lawyers: This issue may be reasonable due to the fear of hordes of foreign lawyers coming in especially when they directly represent multinational corporations/.

iv. Need to amend laws or constitutions: Some countries just are not able to overcome their national sensitivities in permitting a foreign lawyer to practice in their territory and there may be a need to amend laws or even the Constitution for this change to happen.

With the disadvantages however, there are some advantages that come with it too, such as $^{27}$ :

i. Increase in Competitive Edge: Lawyers will have to continuously update

${ }^{24}$ Anonymous, 'SGU Pioneers the Realization of AEC 2015 Impact in Higher Education Sector' http://www.sgu.ac.id/sgu-pioneers-realization-aec-2015-impact-higher-education-sector accessed on 6 December 2014.

${ }^{25} \mathrm{Hjh}$ Nor Hashimah Hj Mohd Taib, 'Resolving Present Legal Issues Under the ASEAN Charter' < http://www.asean lawassociation.org/10GAdocs/Brunei2.pdf> accessed 25 November 2014.

${ }^{26}$ Anonymous, "PERADI wajibkan Advokat Asing Ikuti PKAA Sebelum Ujian' (Jakarta, 27 August 2014) <http://www.hukum online.com/berita/baca/lt53fd99fe488a9/peradi-wajibkan-advokat-asingikuti-pkaa-sebelum-ujian>, accessed 1 December 2014; See Peradi, THE NAME WHO HAVE PASSED THE 2014 EXAM FOR FOREIGN ADVOCATES II (30 September 2014) <http://peradi.or.id/index.php/berita/ detail/the-name-who-have-passed-the-2014-exam-for-foreign-advocates-ii\#sthash.ZViahdJp.dpuf> accessed on 4 December 2014

27 Ibid. 
themselves with current law internationally or face lower market exposure from foreign players. With the introduction of foreign law firms coming in and sharing their turf, this may actually encourage them to improve their services so they will not lose their clients to the newer law firms coming in.

ii. Transfer of knowledge: Fresh law graduates will have better opportunities to pursue internship with prominent experienced foreign law firms, increasing their exposure to international business climate.

iii. Infiltration of Local Lawyers to Practice Abroad: local lawyers will be able to facilitate the free flow of services and establishment within ASEAN if the governments of ASEAN Member States decide to make Mutual Recognition Agreements with them. ${ }^{28}$

iv. Joint Ventures: joint ventures between a local law firm and foreign law firm will enable multiple companies to navigate the mired national bureaucracy and provide better assurance to national legal system.

v. Increased FDI: The establishment of the foreign law firm, especially a prominent one can signal an incoming foreign direct investment into the host country. The government may put additional tax or income from law firm that employs foreign lawyers or foreign law firms that opens branch in Indonesia. That additional income maybe used to develop the quality of Indonesia's law in the future.

MEA brings consequences for educators and legal professionals alike as the following:

i. Indonesian legal education should pursue a clearer goal aside from maintaining good accreditation and large number of graduates. They should seek cooperation with profession organization to provide value added training for students such as incorporation for lawyer exam or international law certification on ASEAN level. In this way, students when graduating can focus on seeking their career or competing abroad instead of pursuing certification elsewhere.

ii. Current legal professionals should push for international legal certification if they wish to be acknowledged abroad. Indonesian legal market share is currently eroded by foreign legal consultant or lawyers pursuing national assimilation exam in Indonesia. The best way would be on the offensive and penetrate international market since most ASEAN legal market remains undeveloped.

\section{Recommendation and Conclusion}

\section{A. Recommendation}

Based on the following chapter, the author came up with the following recommendation:

1. While liberalization is something for the governments of the respective ASEAN Members States to decide on, however as an entity recognized under the

${ }^{28}$ Anonymous, 'Asean Mutual Recognition Arrangement Framework on Accountancy Services', < http://www.thaifta .com/trade/ascorner/asser_71.pdf>; See also, the Asean Secretariat, 'Handbook ASEAN Mutual Recognition Arrangement (MRA) on Tourism Professionals' (Januari 2013) <http://vietnamtourism.gov.vn/english/ dmdocuments/MRA-TOURISM-PROFESSIONALS-HANDBOOK-V21-20-122012-FINAL-for-ATF.pdf> accessed 1 December 2014 
ASEAN Charter, Indonesian governments may seek guidance from regional law association such as Asean Law Association to achieve standard goals for Indonesian graduates

2. We can build on the cooperation we have and increase awareness of the various areas that are of concern amongst members e.g. recognition and enforcement of commercial judgments, familiarization of legal systems of each member. Actions such as exchange of information, sharing of experiences, undertaking transparency exercises in legal systems, legal traditions and legal practices would all be very valuable to have amongst members to enable us to have a clearer understanding of what needs to be done for liberalization and in turn we would be prepared for any eventuality once liberalization does happen in Indonesia by 2015.

3. Half a year towards 2015 and Indonesia will be carrying out the largest regional economic policy as member of the Association of South East Asian Nations (ASEAN). The dream was to create an ASEAN Economic Community (AEC) based on agreement between state members at the $13^{\text {th }}$ ASEAN High Summit Conference in Singapore on Nopember 2007. With a definite deadline on 2015, the initiative came with AEC Blueprint as a baseline to create a free flow of goods, services, investment, labors and capital among state members. Enactment and implementation of ASEAN Single Window (ASW), evaluation the Common Effective Preferential Tariff (CEPT) Scheme, Rules of Origin (ROO) offers standard and conformance. However, all of this scheme must be supported by a change of paradigm in Indonesian legal education sector if law graduates wanted to be a part of ASEAN and not only Indonesia.

4. The education sector has been categorized into free flow trade of services that demanded removal of restrictive barriers and relaxation of foreign entry to the national market. Indonesian HEI manager needs to adopt international ASEAN standards on current legal curriculum in order to survive in the international trade ear.

\section{B. Conclusion}

Based on the following chapter, the author came up with the following conclusion:

1. The issue remains that Indonesia is struggling to tackle legal HEI issues due to lack of funds and manpower. Article 31 of 1945 Constitution only covered government obligation for basic education and state budget allocation would never be suffice to accommodate all levels of education. Therefore, the society has to shoulder the responsibility of developing nations in higher education.

2. HEI must establish appropriate skills and research will help Indonesia to achieve productiveness, creativity and growth rate in a competitively global environment. While state university may enjoy decades or even centuries of reputation for this matter, private university needs to promote a cutting edge, a specialized service, international cooperation with world Class University or professional certifications to attract potential students. It is little wonder that young generations are getting more convenient with information technology and HEI entity that refuses to revolve may end up being left by the market or produce unmarketable graduates.

3. The impact of free trade to higher education will create a boom in academic relations between graduates and institution. Indonesian professionals maybe 
startled witnessing savvy graduates from Singapore that can speak in multilingual manner or offer business proposals while Thailand graduates is equipped with international network and certifications in his field. From a whole perspective, Indonesia's higher education should consider not only its standard but also international standards.

4. Free trade poses another challenge to institution as the non-profit aspect clashes with international pressures of trade. Influx of foreign capital or offers from foreign institutions may compromise the integrity or way of thinking regarding the dogma of higher education. And for that, the only solution would be to strengthen the coordination between foundation and university. With each separate authority in management and pure academic activity, university will have better chance to reach its mean and purpose of national education.

5. Overall, Indonesia's national higher education still has a long way to go but management excellence remains an open possibility to manage risks of free trade into beneficial opportunities.

\section{Bibliography}

\section{i. Legal Documents}

Asean Economic Community Blue Print

Law No. 20 Year 2003 concerning National Education System

\section{ii. Books}

Darmaningtyas et al. (2009) Tirani Kapital Dalam Pendidikan : Menolak UU BHP (Badan Hukum Pendidikan). Jakarta: Damar Press.

Dicey,A V. (1989). Introduction to the Study of the Law of Constitution, 3rd Ed. London: Macmillan.

Siswoyo, Dwi, et al. (2007). Ilmu Pendidikan. Yogyakarta: UNY Press.

\section{iii.Websites}

Ana Suhaenah, Adam Pamudji Rahardjo, BAN-PT, the National Accreditation Board for Higher Education with One Decade Experience in Indonesia. < http:// siteresources.worldbank .org/EDUCATION/Resources/indonesia_ban-pt.pdf> accessed on 7 December 2014.

Anonymous, 'Asean Mutual Recognition Arrangement Framework on Accountancy Services', < http://www.thaifta .com/trade/ascorner/asser_71.pdf>;

'PERADI wajibkan Advokat Asing Ikuti PKAA Sebelum Ujian' (Jakarta, 27 August 2014) <http://www.hukum online.com/berita/baca/ lt53fd99fe488a9/peradi-wajibkan-advokat-asing-ikuti-pkaa-sebelum-ujian>, accessed 1 December 2014;

2011'Kajian Analisis Sistem Akreditasi Program Studi dalam Rangka Reformasi Birokrasi Internal'< http://luk.staff.ugm.ac.id/atur/rbi/ AkreditasiProdi.pdf $>$ accessed on 3 December 2014.

'BAN Accreditation of the Ministry of National Education of Republic of Indonesia', <http://feb.ugm.ac.id/en/accreditation/ban-pt-accreditation. html $>$, accessed on 4 December 2014.

'SGU Pioneers the Realization of AEC 2015 Impact in Higher Education Sector' http://www.sgu.ac.id/sgu-pioneers-realization-aec-2015-impact- 
higher-education-sector accessed on 6 December 2014.

,(9 November 2013) 'Dana Terbatas, Belum Semua PT Terakreditasi'< http:// www.pikiran-rakyat.com/node/257882> accessed on 6 December 2014.

. (7 February 2009) Mendiknas: Silahkan Gugat UU BHP < http://nasional. kompas.com / read/2009/02/07/15021516/mendiknas .silakan.gugat.uu. bhp>, accessed 6 December 2014

Dasar Hukum Pendidikan di Indonesia. http://englishclass-b.blogspot. com/2013/12/dasar-hukum-pendidikan-di-indonesia.html, accessed on 7 December 2014

, 'Info Lengkap Fakultas Hukum', <http://old.ui.ac.id/id/academic/page/fh> accessed on 12 December 2014

'Preparing An Entrepreneurial Generation That Will Become Future Leaders' < http://www.tarumanagara.ac.id/read-isi_berita-eng-468.html> accessed 8 December 2014

Asean Secretariat, 'ASEAN Economic Community Blueprint' (Jakarta: January 2008) <http://www.asean.org/ archive/5187-10.pdf> accessed 30 November 2014

ASEAN Secretary "ASEAN region on track for 2015 integration" (7 July 2013) Inquirer Business (available online:http://business.inquirer.net/130941/aseanregion-on-track-for-2015-Integration (last accessed 9 July 2013))

Jeremy Grant, "Legal hodge-podge frustrates Asean harmonization" (21 August 2014) < http://blogs.ft.com/ beyond-brics/2014/08/21/legal-hodge-podgefrustrates-asean-harmonisation/> accessed 28 November 2014

Lucia Ratih Kusumadewi and Antonius Cahyadi, The Crisis of Public Universities in Indonesia (29 June 2013) <http://www.isa-sociology.org/universities-incrisis $/ p=1010>$, accessed 6 December 2014

Menon, Sundaresh, 'ASEAN Integration Through Law'< http://app.supremecourt.gov. sg /data/doc/ManagePage/4943/ASEAN\%20Integration\%20 Through\%20 Law\%20 Project \%20 Keynote.pdf > accessed on 2 December 2014

Peradi, THE NAME WHO HAVE PASSED THE 2014 EXAM FOR FOREIGN ADVOCATES II (30 September 2014) <http://peradi.or.id/index.php/berita/detail/thename-who-have-passed-the-2014-exam-for-foreign-advocates-ii\#sthash. ZViahdJp.dpuf $>$ accessed on 4 December 2014

Purbayanto, Ari. 'Menyingkapi Pro dan Kontra UU BHP', <http://sa.ipb.ac.id/index. php/sorotan-utama/16-menyikapi-pro-dan-kontra-undang-undang-bhp. html >, diakses tanggal 5 Desember 2014

Reksodiputro, Marjono' Challenges to Legal Education in Indonesia'. <http://www. asean lawassociation.org /docs/w3_indo.pdf> accessed on 12 December 2014

Taib, Hjh Nor Hashimah Hj Mohd, 'Resolving Present Legal Issues Under the ASEAN Charter' < http://www.asean lawassociation.org/10GAdocs/Brunei2.pdf> accessed 25 November 2014.

The Asean Secretariat, 'Handbook ASEAN Mutual Recognition Arrangement (MRA) on Tourism Professionals' (Januari 2013) <http://vietnamtourism.gov.vn/ english/dmdocuments/MRA-TOURISM-PROFESSIONALS-HANDBOOK-V2120-12-2012-FINAL-for-ATF.pdf> accessed 1 December 2014.

The Institution of Engineers Singapore (25 February 2013) , 'Asia Pacific Economic Cooperation Engineers Register' < http://www.ies.org.sg/pageview.php?page_ id=346> . accessed 6 December 2014.

Yakuub, Mohammad Naim, Challenges in Education Towards The Realization of ASEAN Community 2015, <http://www.site.rmutt.ac.th/cpscworkshop/ materials/sp.pdf $>$, accessed at 12 December 2014 